\title{
ICONIC REPRESENTATION OF BALOCH CULTURE: A SEMIOTIC ANALYSIS
}

\author{
Muhammad Hussain* \\ Muhammad Amjad** \\ Kalsoom Bugti ${ }^{* * * *}$
}

\begin{abstract}
The present paper analyzes cultural attires and appearances of Marri and Bugti tribes in Balochistan to find out latent meanings attached to these artifacts. In doing so, the study uses Peirce's framework of semiotics- an iconic perspective. The analysis has been carried out with the help of close reading (Semiotic perspective) of the cultural images and appearances. The results reveal underlying multi-meanings attached to these images and appearances. The findings reflect the richness and diversity of Marri and Bugti cultures and the invisible representational meanings of these objects. This research endeavor may be helpful to promote pluralism, harmony and enhance intercultural awareness necessary for understanding cultural diversities within and across societies. More so, future researchers can explore cultural objects and appearances of Punjabi, Sindhi, Pashtuns, Urdu speaking, and Saraiki people by applying various frameworks of semiotics.
\end{abstract}

Keywords: Semiotics-iconic, culture, appearances, attires, Baloch (Marri \& Bugti)

\section{Introduction}

The present paper attempts to analyze cultural appearances and attires of Marri and Bugti people who live in district Kohlu, Kahaan, Dera Bugti.Sibi, Harnai, Quetta, Turbat, Khuzdar and Lasbela (Hub) located in Balochistan, Pakistan. The paper focuses on latent meanings attached to the cultural attires and appearances of these communities, thus Semiotics is the lens that deals with how languages, images and objects carry meanings. In the post-modernism era, the focus is on marginalized and indigenous languages, cultures and people; hence the present study focuses on indigenous cultures i.e. Marri and Bugti as social scientists play a constructive role for harmonizing societies through interaction in terms of research work. As a result of research works, the studies regarding cultural awareness may promote social harmony within or across societies.

Culture, the collective programming of the mind, distinguishes the members of one group from others ${ }^{1}$. Along the same line, a culture has been termed as a shared system,

This work is Licensed under a Creative Commons Attribution-Non-Commercial 4.0 International License (c) (1) (9)

\footnotetext{
*Muhammad Hussain, Ph.D. Scholar, Department of English, International Islamic University Islamabad, Pakistan

${ }^{* * *}$ Muhammad Amjad, Ph.D. Scholar, Department of English, International Islamic University Islamabad, Pakistan

****Kalsoom Bugti, MS student, Department of English, Sardar Bahadur Khan Women's University Quetta
} 
which conveys meanings. It dictates what we pay attention to, how we act, and what we value $^{2}$. In the same vein, culture has been conceptualized through taxonomies as bi-polar dimensions i.e. a) collectivism vs. individualism, and b) universalism vs. particularism ${ }^{3}$.

Additionally, characteristics which are common to a particular group of people indicate shared values of a culture. These characteristics are learned, not given by nature ${ }^{4}$. Four primary dimensions have been introduced such as a) patterns of thought; b) patterns of behavior; c) patterns of artifacts, and d) imprints in nature. Furthermore, Culture is usually compared to an ice berg which has visible and invisible parts: above the surface and below the surface ${ }^{5}$. The part which is above the surface is visible and it consists of language, food, greeting, and dress; however, the biggest part of the culture which is hidden below the surface: the invisible rules, meanings and values that define each culture. The image of a cultural iceberg:

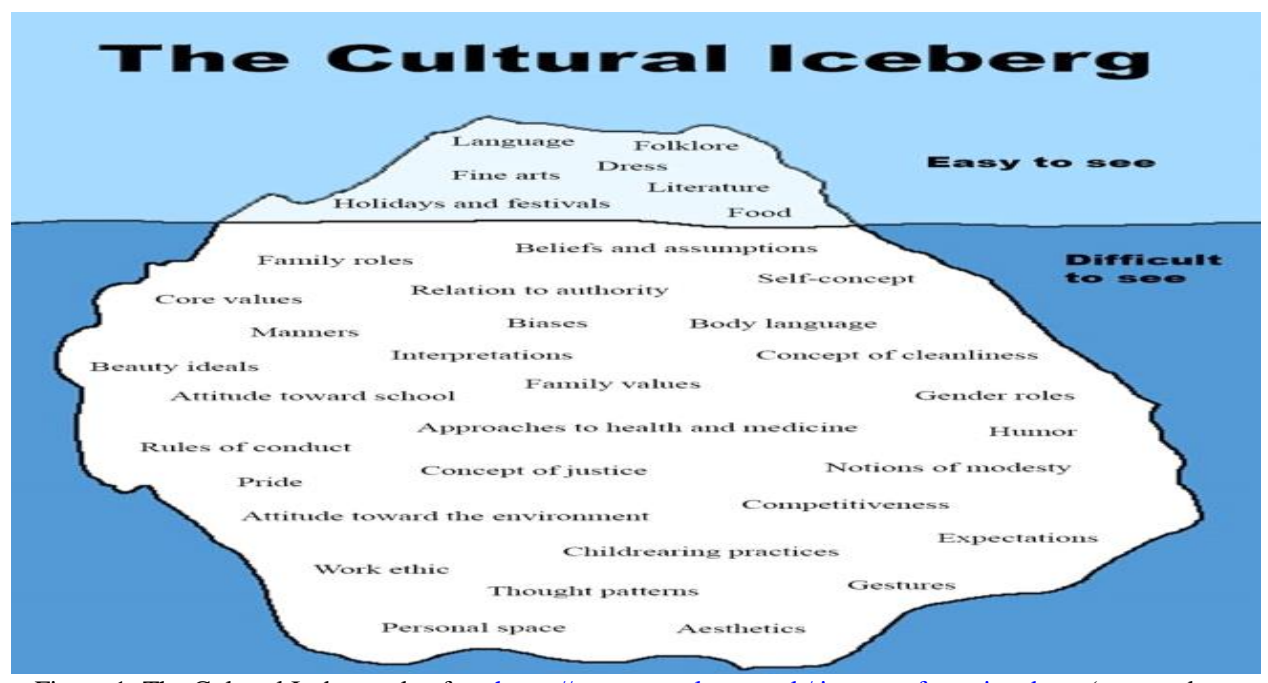

Figure 1: The Cultural Iceberg takenfromhttps://www.google.com.pk/ image+of+an+ice+berg (accessedon January 25, 2018)

Awareness of cultural diversities may reduce ethnic conflicts between communities and may increase harmony in society. Cultural awareness provides an understanding of the different cultural rules and behaviors that exist, how we react to these differences and how to avoid misunderstandings to improve intercultural awareness and communication. Moreover, Culture has been defined as a complex phenomenon. It includes knowledge,

1. Hofstede, Geert, Culture's Consequences: International Differences in Work-Related Values, (Beverly Hills: Sage, 1980).

2. Trompenaars, Fons, and Charles Hampden-Turner.Riding the Waves of Culture: Understanding Diversity in Global Business. (Nicholas Brealey Publishing, 2011).

${ }^{3}$. Hofstede, Geert, 1980 \& Trompenaars, Fons, 2012.

4. Allwood, Jens, Intercultural Communication, (Anthropological Linguistics, 1985), 12, 1-25.

5. Katan, David, Translating Cultures: An Introduction for Translators, Interpreters and Mediators, $2^{\text {nd }}$ Ed., (Manchester: St. Jerome, 2004) 
belief, art, morals, law, custom, and all other capabilities and habits acquired by a person as a member of a society ${ }^{6}$.

On the other hand, Arnold in "Culture and Anarchy" defines culture spiritually. He defines culture as "culture consists of two components: One is lamp and the other is sweetness. Light means enlightened mind and sweetness means your decency of conduct: how do you treat others" ${ }^{\text {". }}$. On the other hand, as the world is progressing fast and so are the technology and science, thus it has become essential and possible in this era of globalization to be aware about diverse societies and their cultural values and attitudes in order to avoid any misunderstanding towards other cultures. It may further improve intercultural awareness and communication. Along these lines, it is of incredible significance to figure out how to impart successfully and get significant information of distinctive societies and cultures. Research articles are platforms which join world economy, science, innovation, culture and society from diverse regions. They indicate new originations and strategies, as well as reflect components of different cultural societies.

Literary theory offers various lenses through which text, signs, cultural attires and various genre of literature can be interpreted in different dimensions. Semiotics is the lens through which one can reveal the hidden meanings which are below the surface of cultural attires and appearances of individuals, since semiotics deals with how languages, images and objects carry meanings. Additionally, it is the study of signs and a sign is a kind of symbol which can be seen in everything. One can find them around human beings, positioned everywhere i.e. in words; in human gestures; in national flags, in cultural attires and appearances; in traffic ways; hence, in every object which can be called as signs.

According to semiotic perspective, one can only know about reality and culture by means of the sign which is called the process of the signification. Furthermore, semiotics is a framework through which, signs are interpreted because of its method and role $^{8}$. Emberto argues that semiotics is concerned with signs and a sign is everything which is a substitution for something else. It is not essential that the something else should exist at the moment in which a sign stand in for it ${ }^{9}$. One of the twentieth-century influential founders of the semiotic approach Ferdinand de Saussure who is known as father of modern linguistics begins with his theory of sign in which he argues that language is a system of sign which can be used to express ideas and meanings. Saussure classifies linguistic signs into two components: the signifier (the sound, image, or word) and the signified which is the concept the signifier represents, or the meaning ${ }^{10}$.

7. Tylor, Burnett Edward, Primitive culture: Researches into the Development of Mythology, Philosophy ,(USA: The University of Michigan, 1871), 1.

7. Arnold, Mathew, Culture and Anarchy, (J. D. Wilson, ed. Cambridge, Cambridge University Press, 1869), 17.

8. Sobur, Alex. Analisisteks Media: Suatu Pengantar Untuk Analisis Wacana, Analisis Semiotik Dan Analisis Framing. ISBN: 9796921421, 9789796921423 (Bandung, Indonesia: Remaja Rosdakarya, 2001).

9 . Emberto, Eco, A Theory of Semiotics, (Bloomington: Indian University Press, 1979).

10. Saussurede Ferdinand, Course in General Linguistics, (New York: Mcgraww-Hill Paperbacck, 1972). 


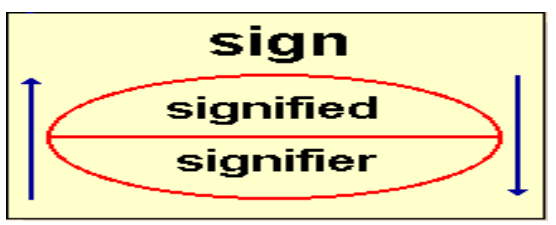

Figure 2: Saussure's dyadic model; taken from http://visualmemory.co.uk/daniel/Documents/S4B/ (accessed on February 6, 2018).

Though, the relation between signifiers and signified has been termed as arbitrary and conventional; however, it is not the case with images because the problem of meaning arises from the arbitrary and conventional nature of signs ${ }^{11}$. The arbitrariness is true in most written and spoken languages; however, it is clear that visual signs or images are not arbitrary in terms of meanings. Since, Saussure was formulating his model of the sign, the American Pragmatic philosopher, logicians as well as one of the founders of Semiotic approach Charles Sanders Pierce defines sign as something which stands to somebody for something for some respect. He designs a triangle-meaning model in order to understand sign. It consists of sign, object, and interpretant ${ }^{12}$.

Here is the pierce' model of sign:

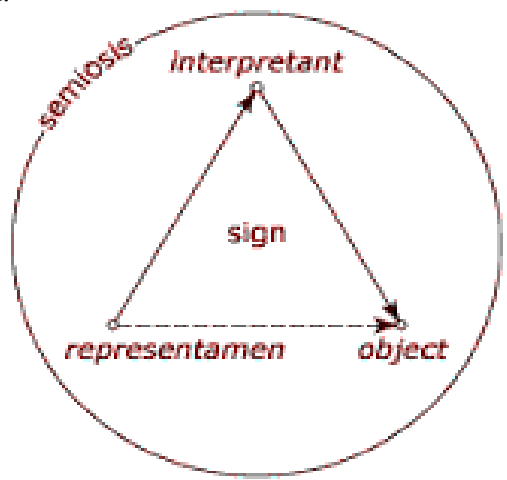

Figure 3: Peirce dyadic model; taken fromhttps://www.google.com.pk/+model+of+sign+image (accessedonFebruary 9, 2018).

As, it can be seen in the above diagram in which 'Representamen' is the form which the sign takes and which is not necessarily material,(2) The 'Interpretant' is not an interpreter but the sense made of the sign, (3) An 'object' to which the sign refers. According to Peirce's perspective, a sign is a concrete thing that is visible and it represents another thing beyond it. Similarly, the present study finds out the meanings which are below the surface and they are invisible; however, only the cultural images and appearances are visible. Peirce categorized the patterns of meaning in signs as iconic, symbolic and indexical. Iconic is a connection between sign and object that looks like what it represents- e.g. the cultural images and appearances. A sign consists of symbol, shows the connection between sign and object because of the convention on the

${ }^{11}$. Barthes, Roland. Elements of Semiology. (Basingstoke, UK: Macmillan, 1977).

12. Pierce, Sanders Charles, The Collected Papers of C. S. Peirce, 1-6, ed. Charles Hartshorne and Paul Weiss; vols. 7-8, ed. A. W. Burks (Cambridge: Harvard, 1931-66). 
social agreement- e.g. flag or the Statue of Liberty is determined by convention--in other words, its meaning is arbitrary; it is based upon agreement and learned through experience.

Language uses words as symbols that have to be learned. An indexical sign shows the connection between sign and object and its causalities, for example, smoke is a sign of fire; icicles means cold. However, one can find difference between Ferdinand de Saussure and Charles Sanders Pierce approaches to Semiotics. Most of the semioticians point out that Saussure's semiotic is the model of semiotic signification whereas Pierce's model has been defined in terms of semiotic of communication. Saussure's model has a focus on the sign as system and structure and denies the use of sign in a process of communication whereas Pierce's model is concerned with process of sign interpretation.

The three sign types can be schematized as below:

\begin{tabular}{|l|l|l|l|}
\hline Sign type & Icon & Index & Symbol \\
\hline Semiotic mode & Similarity & $\begin{array}{l}\text { Cause or natural } \\
\text { relation }\end{array}$ & Convention \\
\hline & $\begin{array}{l}\text { Photograph } \\
\text { Painting }\end{array}$ & $\begin{array}{l}\text { Smoke for fire } \\
\text { Symptom for disease }\end{array}$ & $\begin{array}{l}\text { Word } \\
\text { Indisiginia }\end{array}$ \\
\hline $\begin{array}{l}\text { Practical } \\
\text { Example }\end{array}$ & $\begin{array}{l}\text { Diagram } \\
\text { Touch of silk } \\
\text { Musical note } \\
\text { Sweet smell }\end{array}$ & $\begin{array}{l}\text { Thermometer for heat } \\
\text { Crash for falling } \\
\text { Feel of fur for cat tail } \\
\text { Sour taste lemon }\end{array}$ & $\begin{array}{l}\text { Morse code } \\
\text { Logical sign } \\
\text { Algebraig sign }\end{array}$ \\
\hline
\end{tabular}

(Note: Adapted from AsriHasanah's work, Vovember 2016, p.13)

Dress is considered as non-verbal communication. Dress and appearance have some social and cultural significance for people in various societies as culture encompasses objects and symbol, thus the meanings that are given to those objects and symbols, the norms, cultural values and beliefs that pervade social life. Thus, appearances and dresses have cultural significance. They convey meanings in various societies. Though, they may seem as merely pieces of clothes or folded bearded, however, they have underlying meanings. Thus, the researchers are to see under the surface of cultural ice-berg and dig out their cultural significance and meaning which may create cultural harmony among societies as Pakistan is rich culturally and it has much cultural diversity in terms of dresses and appearances.

Gohil and Sidhu describe that turbans are worn by people in various cultures across the world for 3000 years. They further go on to assert that the turban carries deep religious significance in Sikh community in India. Besides, they further reveal that Sikh turbans have taken a new meaning in the aftermath of terrorist attack of September 11, 2001 as non-Sikhs tend to associate Sikhs' turbans with Osama bin Laden. Thus, it can be said that certain cultural appearances and dresses do convey meanings. Thus, attires or appearances are symbols which convey meanings and a symbol is an entity that 
represents some other entity ${ }^{13}$ and according to semiotic approach, fashion (attires or appearances) is a language and is therefore systematically organized one. Thus, this perspective emphasizes the visual language of fashion ( attires or appearances ) with grammar , syntax and vocabulary ${ }^{14}$, similar to the linguistic code, clothing and fashion ( including appearances have denotative ( literal ) meaning and connotative ( implied, symbolic ) meaning ${ }^{15}$.

The present study explore the connotative latent meanings of attires and appearances of Baloch and Bugti tribes which may be a contribution in terms of semiotic study of dresses and appearances of one of the communities i.e., Baloch and future researchers may also try to explore underlying meaning in their cultural appearances and dresses. Such studies may play a role of bridge to understand the cultural differences that exist in all provinces of Pakistan that may create social harmony in Pakistani society. We further argue that we are well aware of meanings conveyed by minor symbols (symbolism) used by English writers in pre-modern, modern and post-modern era; however, we do not have the understanding of the meanings conveyed by our own cultural dresses and appearances in Pakistani societies. Hence, such studies may be beneficial for cultural studies domain, not only in Pakistan but also these studies may convey cultural significance of Pakistani cultural dresses and appearances across the world.

The present study explores underlying meanings in cultural attires and appearances of Marri and Bugti tribes. The data have been collected from social media page of 'Marri and Bugti culture'. This page is relatively more reliable and credible as it has been made to promote Marri and Bugti culture, thus we can say that the page is comparatively reliable and authentic.

As far as application of the model of signification is concerned, two of the researchers of the paper are native Marri and Bugti from Balochistan, thus keeping in mind the lenses of semiotics, researchers have closely observed their cultural dresses and appearances which carry meaning as semiotics made us conscious of the underlying meanings of these cultural attires and appearances. On the selected attires and appearances, Peirce's $\mathrm{s}^{16}$ framework of semiotics- an iconic perspective was applied as it is said that the arbitrariness is true in most written and spoken languages; however, it is clear that visual signs or images are not arbitrary in terms of meanings.

\footnotetext{
${ }^{13}$ Morris, Charles. Signs, Language and Behavior. (New York: George Braziller, 1946).

${ }^{14}$ Barthes, Roland. The semiotic challenge. (University of California Press, 1994)./Floch, Jean-Marie. Visual identities. (Bloomsbury Publishing, 2005). /Lurie, Alison. The language of clothes. (Random House Inc, 1981).

${ }^{15}$ Barnard, M. Fashion As Communication. (London; New York: Routledge. 1996).

${ }^{16}$. Pierce, Sanders Charles, Op.cit.
} 


\title{
Analysis
}

\section{Semiotic Analysis of the Cultural Images of Marri and Bugti Tribes}

\author{
Image - 1 \\ A Child with Cultural Turban
}

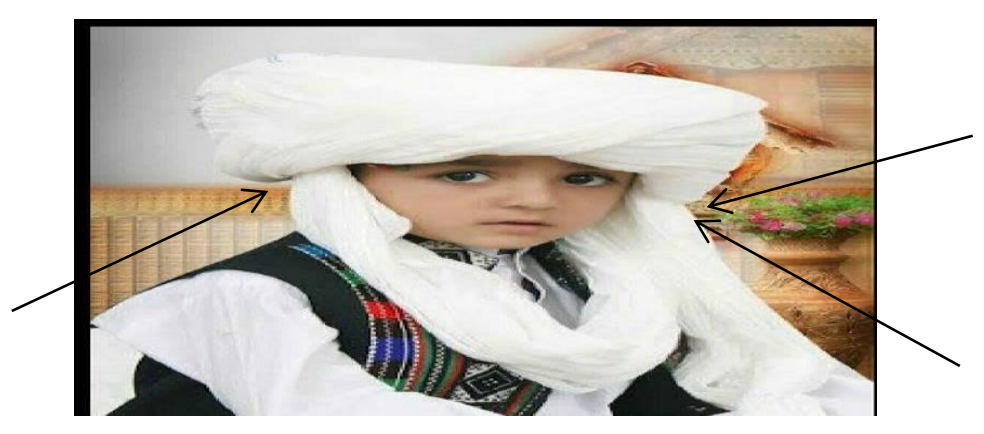

(Taken from https://www.facebook.com/Marri-culture (accessed on February, 18, 2018).

The above image 1 is of a child with cultural turban which is called 'Phagh' in Baloch culture particularly in Marri and Bugti tribes. The turban has cultural significance among these tribes.Gohil and Sidhu describe that turbans are worn by people in various cultures across theworld for 3000 years. They further go on to assert that the turban carries deep religious significance in Sikh community in India ${ }^{17}$, however, it carries cultural significance among Baloch particularly Marri and Bugti tribes in Balochistan. Gohil and Sidhu further reveal that Sikh turbans have taken a new meaning in the aftermath of terrorist attack of September 11, 2001 as non-Sikhs tend to associate Sikhs' turbans with Osama bin Laden ${ }^{18}$. According to them turbaned Sikhs in America have been victim of racial violence and have had their identity challenged by calls for immigrant groups to assimilate into Western societies. A number of references can be found in The Old Testament regarding turbans. Turban was worn by Moses that symbolizes his status as a prophet, holiness, and divine power ${ }^{19}$ which shows the relevance of wearing a turban to Islam ${ }^{20}$.

Turbans are worn by various groups across cultures for a number of reasons in South Asia. Bejeweled turbans are worn by wealthy people which are symbol of their power, prestige, and royalty. Along the same line, turbans are also worn to show class difference in various cultures as high caste Hindus wear turbans to differentiate themselves from lower castes ${ }^{21}$. Additionally, turbans are also worn by men. They

\footnotetext{
17. Sidhu, Dawinder S \& Gohil, Singh Neha, The Sikh Turban: Post 9/11 Challenges to ThisArticleto Faith (Rutgers Journal of Law and Religion, 9: 2, 2008), 1.

${ }^{18}$.Sidhu \& Gohil, Op.cit, 2008.

19. Sikh Blog, Sikh Theology Why Sikhs wear a Turban, retrieved from http://igurudwara.com/wpcontent/uploads/2016/02/Sikh-Theology-Why-Sikhs-wear-a-Turban.pdf .(accessed on February 22, 2018)

${ }^{20}$. Sidhu \& Gohil, Op.cit.2007.

${ }^{21}$ Ibid.
} 
protect them in desert regions and rural areas from dust and heat ${ }^{22}$. Besides, turbans also symbolize good faith and hospitality in a dealing or agreement ${ }^{23}$.

Marri people in Balochistan usually buy white cloth for turban because white colour signifies one segment of Marri tribe i.e. Ghazeni; the black colour signifies the second, i.e. Bijarni and grey colour signifies the third segment of the Marri tribe; Loharani. Turban in Marri culture signifies living among people with honor and dignity. The Marri people who are followers of their culture never miss their turbans whenever they go to any marriage ceremony or any 'Merh' which is a kind of gathering of tribal elders in order to sort out tribal disputes. The elder sit together and both the disputed parties are directed to sit and express their grievances and problem which are resolved peacefully by tribal elders who wear turbans. The one who comes without turban is usually considered unethical and against the norms and values of the Marri and Bugti tribes.

The 'Phagh' is identical for every tribe and differs in style and size both so as in Bugti tribe. In Bugti tribe identical phenomenon is even unique. The right side fold line particularly known as 'Perozani Bugti style' which signifies an individual who belongs to Perozani sub-tribes of Bugti community, who dwell in the eastern and north eastern areas of Bugti lands bordering Marri and Domki tribes. Whereas the straight 'Phagh' signifies people in eastern and southern region of Bugti tribe. This arrangement was once deliberately managed to limit the tribal clashes to sub-tribes as these tribal clashes normally resulted in heavy bloodshed and the enmity continued for decades.

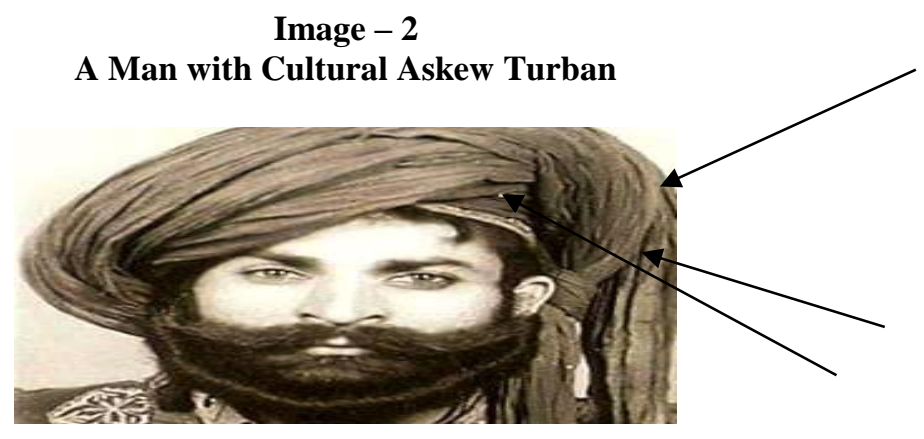

(Taken from https://www.facebook.com/Marri-culture (accessedonFebruary 22, 2008)

The above image 2 is a Marri man with askew turban askew. Turban is worn in two ways by Marri and Bugti people: one is straight which signifies more formal, is usually adopted by tribal elders whenever any tribal gathering is attended i.e. gathering in order to sort out any tribal disputes; marriage ceremony; however, askew turban is usually adopted by youngsters which signifies as informal and it is usually adopted by the ones

22 . Schmid,Paul, Understanding Turbans, (The Seattle Times, NA), Retrieved fromhttp://www.sikhinterfaithvic.org.au/Understanding\%20turbans.pdf. (accessed on February 23, 2018).

23. The Koh-i-noor Diamond BBC, (2002). retrieved fromhttp://www.bbc.co.uk/dna/h2g2/A730801. (accessed on February 23, 2018). 
who are emotionally lively and vivacious or to some extent, it signifies love attachments to beloved. Turbans are also worn to show political affiliations ${ }^{24}$. In recent years, turbans have also emerged as a stylish accessory for American artist ${ }^{25}$. Additionally, an authentic Sikh turban has been worn by legendary jazz musician Dr. Lonnie Smith for no particular reason ${ }^{26}$ In addition; a turban has been worn by Andre " 3000 " Benjamin in order to look cool. Further, turbans have been worn by several celebrities such as Jennifer Lopes, Katie Holmes, Ralph Lauren, and Marc Jocobs ${ }^{27}$. Moreover, the askew turban is worn by Marri and Bugti people intentionally because it usually signifies young age. Cap is slightly visible in the image which is shown deliberately. The slight part of the cap signifies that it is not only the turban but cap is also there because wearing turban without cap signifies unethical nature of individuals. The young men among Marri tribe show a part of cap intentionally which also signifies beauty. It is usually done by young people because of their emotional attachments.

Various biased approaches can also be seen across world regarding turban such as two independent surveys i.e. Google Consumer survey and Politix were conducted regarding turbans in America $^{28}$. The results of their study reveal that: a) Americans tend to associate turbans with Osama bin Laden and because of wearing turban $49 \%$ Americans believe that Sikh is a sect of Islam ${ }^{29}$. Politix Surveys reveals that $20 \%$ of the American respondents are of the view that if they encounter a man in turban, they are likely to become angry and apprehensive. The results of the survey reveal that turban is considered as an object of enmity which affects the perception of its wearers whoever they happen to $b^{30}$. Gohil and Sidhu are of the view that one should be mindful of the fact that turbans have religious and cultural significance across the world ${ }^{31}$ so as it has cultural significance in Marri and Bugti tribes in Balochistan.

24. Sidhu\&Gohil, Op.cit.2007.

${ }^{25}$. Milkowski\& Smith, Loonie,The Doctor Is In!, JAZZ TIMES, retrieved from

http://jazztimes.com/columnS_and_features/table_of_contents/article_excerpts/index.cfm?articl_id=15242,

( accessedonFebruary 24, 2018).

${ }^{26}$. Sidhu \& Gohil, Op.cit.2007.

${ }^{27}$. Ibid.

${ }^{28}$ Stanford Peace innovative Lab, Turban myths: The opportunity and challenges forreframing a cultural symbol for post 9/11 America, (Stanford California, 2013).

29. Stanford Peace innovative Lab, Op.cit, 2013.

${ }^{30}$. Ibid.

31. Gohil \& Sidhu, Op.cit, 2007. 


\section{Image - 3 \\ a) The Image of a Girl with "Tokh" (neck ring), and b) The Image of Bugti Women Dressed in White Kameez with Colored Shalwar, and Red Head Scarf}

(A)

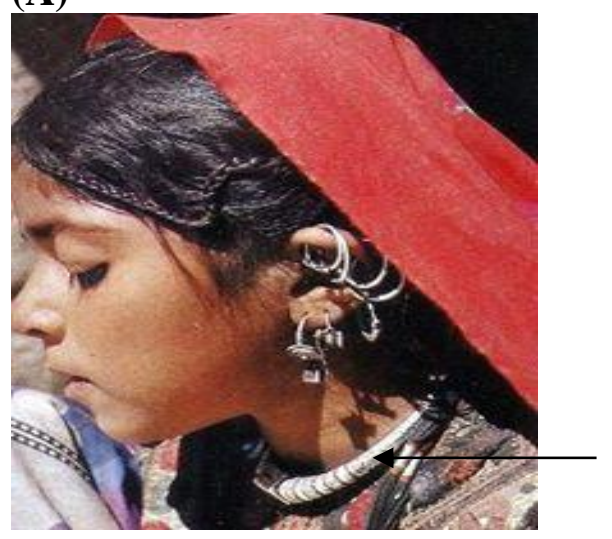

(B)

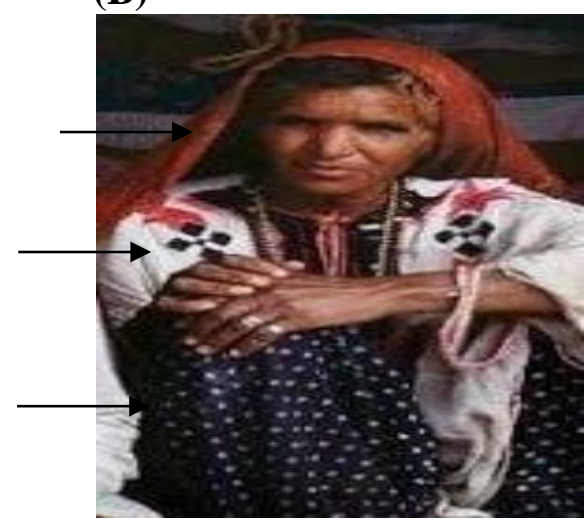

(Retrieved from https://www.facebook.com/Marri/baloch-culture(accessed on March 4, 2018)

Image 3 ' $a$ ' is a Marri girl who is in her cultural dress including ear rings, cultural hair style and a cultural object which is worn around the neck, called "Tokhh" ( neck ring). The Neck rings are worn across cultures and various myths are attached to it as it is considered as a form of jewellery worn as an ornament around the neck of an individual particularly women. Brass coils Neck rings are worn by women of Kayan tribe in Myanmar in their entire lives in order to lengthen their necks and the belief that is attached to it is; the longer the neck, the more beautiful the woman ${ }^{32}$. On the other hand, neck rings are found inside as well as outside of Scandinavia and that are closely related to the burial rites ${ }^{33}$. A bulk of studies has been carried out on various interpretations of neck rings across cultures.

The 'Tokhh' is significant in Marri and Bugti cultures especially among Women. It signifies a woman who is married, because it is only worn around the neck by married women. However, single women or girls do not put it around the neck. Thus, the 'Tokh' in Marri and Bugti cultures signifies marital life.

In the same image 3(a), the hair style of girl is similar to French braid, which is traditionally called "Mendhi" in Bugti tribe. This specific hair style signifies unmarried girls. The marriage ritual of Bugti tribe includes un-waving of Mendhi, In Bugti tribe

\footnotetext{
32. Korzhov, Nikolay, In pictures: Myanmar's neck ring women. In Pictures,(2013)retrieved fromhttps://www.aljazeera.com/indepth/inpictures/2013/09/2013911121115463797.html. (accessed on March 5, 2018)

${ }^{33}$ Ström, Krister. Torshammarringen — etl $i$ Västmanland unikt vikingatida föremål. Västmanlands fornminnesförenings årsskrift, (1973): 105-117.
} 
early child marriage is very common and un-waving of Mehndi denotes that the girl is woman from day after engagement or marriage. However, the girl having Mendhi style is not single, thus cannot be proposed, because the engaged girls also adopt the same hair style.

On the other hand, a woman in the image 3 ' $b$ ', belongs to Bugti tribe of Baloch community. Women in Baloch folk normally wear colorful dresses but specifically white kameez with simple black or brown embroidery signifies the social permission for women to lead young women of the family and to communicate with strangers in absence of men, as women in such attires are believed to be old and mature enough to safeguard the family prestige.

Image -4

\section{A man with folded/curled beard}

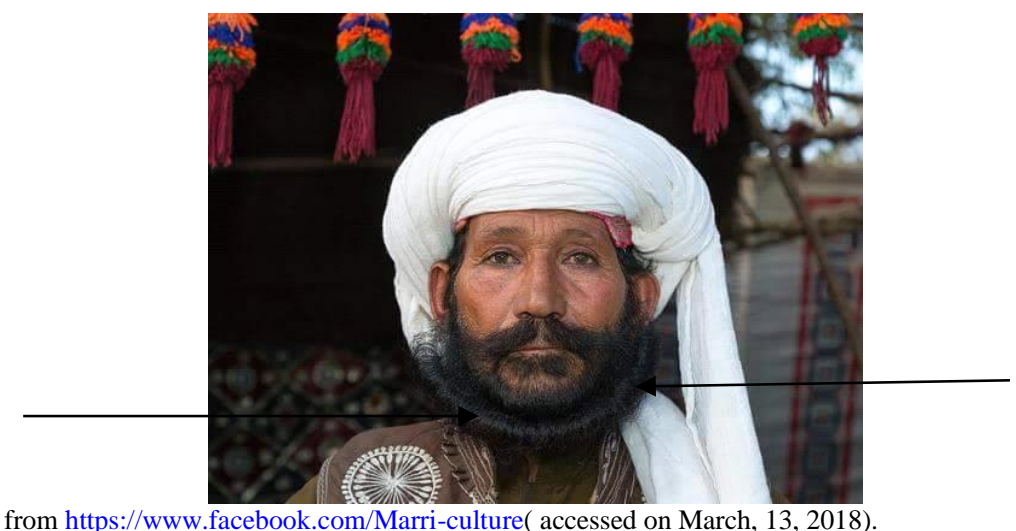

(Taken from https://www.facebook.com/Marri-culture( accessed on March, 13, 2018).

Men with beards feel themselves as more masculine and dominant than clean-shaven ${ }^{34}$. Watkins, Jones, and Debruine are of the view that men with higher self-reported, social dominance and with greater stature are less sensitive to cues of facial dominance rather than men of shorter stature and lower self-reported social dominance ${ }^{35}$. The results of a great deal of studies reveal that facial masculinity and beardedness are usually associated with masculinity and dominance ${ }^{36}$.

The above image 4 is of a Marri man with folded/curled beard. Having beard is one of the important aspects of Marri culture and the folded/curled beard has cultural significance. The folded beard signifies a man who is emotionally attached with his beloved or the ones who considers themselves young as they preen their beards with

${ }^{34}$. Wood, Douglas R. "Self-perceived masculinity between bearded and non-beardedmales."Perceptual and Motor Skills 62, no. 3 (1986): 769-770.

35 . Watkins, Christopher D., Benedict C. Jones, and Lisa M. DeBruine. "Individualdifferencesindominance perception: Dominant men are less sensitive to facial cues of male dominance." Personality and Individual Differences 49, no. 8 (2010): 967-971.

36. Geniole, Shawn N., and Cheryl M. McCormick."Facing our ancestors: judgementsofaggression are consistent and related to the facial width-to-height ratio in men irrespective of beards."Evolution and Human Behavior 36, no. 4 (2015): 279-285. 
care. Folded/curled beard also signifies happiness; however, beards are not folded whenever there is any demise in family or one is going through domestic problems. Furthermore, the folded/curled beard also signifies the ones who consider themselves vivacious; hence, curled beards are perfumed. Moreover, they love to turn their moustaches up which signify bravery and boldness; thus, moustaches are also drenched with scent. Consequently, it can be said in semiotic perspectives that folded beard has cultural underlying meanings.

\section{Conclusion and Suggestions}

The aim of the paper was to explore the underlying meanings in cultural appearance and attires of Marri and Bugti cultures in Balochistan. The analysis of the images show underlying meanings attached to cultural attires and appearances i.e. Turban; askew turban; neck ring, Mendhi (specific hair style); Colorful dresses (white kameez with simple black or brown embroidery) and folded bearded. The analysis shows that turban signifies specific meanings, its color shows certain specific segment of Marri tribe and its style shows specific segment of Bugti tribe. Further, turban also signifies honor and dignity. However, the Askew Turban signifies vivaciousness, love attachments and informality (see image 1,2) as Gohil and Sidhu in their study show some religious and social aspects of turban. Besides, "Tokhh" (neck ring) also signifies some cultural meanings and interpretation as it signifies marital life (see image 3 (a) and "Mendhi" in Bugti tribe, a specific hair style, also signifies the marriage or engagement of a girl so that one may not propose her as proposing a girl when she is engaged, is considered against cultural values and honor, thus specific hair style is adopted (see image 3 (a)) as mentioned in review that Morris, Barthes and Barnard also discuss cultural significance of cultural appearances and dresses. Moreover, the analysis also show colorful dresses signify cultural underlying meanings as white kameez with simple black or brown embroidery signifies the social permission for women in Bugti tribe and Marri tribes ( see image 3 (b). Finally, the folded bearded signifies emotional attachments to beloved and it is also associated with masculinity and dominance (see image 4). Though, other cultural attires and appearances may also signify underlying cultural meanings, however, they were beyond the scope of the present paper because of limitation of a single paper, but few researchers may also explore other attires and appearances.

Culture has certain elements such as a) language; b) dress and appearance; c) food and eating habits; d) music and dance; e) interpersonal relationship; and f) beliefs and attitudes. The study has investigated the meanings attached to some of cultural appearances and attires such as folded beard, Turban (Straight and Askew), neck ring, hair style and dresses (see image 1 to 4). The results of the study reveal that Marri and Bugti cultures are very rich in terms of latent meanings which are not visible. Though, we are aware of various meanings/interpretations attached to symbolism and cultural objects to western world but majority of the people are unaware regarding various meanings attached to our own various Pakistani cultures. Our ignorance towards our own indigenous cultures may results cultural death of communities who live in Pakistan. The future researchers may explore various interpretations attached to their cultures across Pakistan and the present paper may serve as patterns for future researches in this domain. 
It is generally observed that lack of understanding regarding different cultures leads us towards cultural misunderstanding which may result lack of intercultural awareness, intolerance, and ethnical strife among communities within Pakistani Society. Furthermore, the post-modern era which focuses on globalization and pluralism contribute to a diversified community and provide exposure to new cultural perspectives. The lack of cultural awareness can be challenging for student advisors in universities at national and international level who have low intercultural and crosscultural exposure other than their own. Intercultural and cross cultural interactions have many benefits, but only if we are open to other cultures. Consistent intercultural interaction and awareness increase individual's likelihood to challenge personal beliefs and embrace new perspectives ${ }^{37}$.Additionally, if one does not have opportunity to interact to individual of diversified communities personally, thus he/she can make it possible because of the rapid development of science and technology. The communication between different cultures becomes easier, necessary and possible through research works. Research articles are grand platforms which combine world economy, science, technology and culture from different areas.

From this perspective, the present study may fill the gap and open a new dimension at national level to explore latent meanings attached to cultural objects, appearances, and attires which may enhance cultural awareness. Summing up, the present paper was an attempt to enhance cultural awareness within Pakistani society which may result in creating tolerance in the society and help people to understand the cultural diversity within Pakistani society.

\section{Bibliography}

Allwood, Jens. Inter-cultural Communication. Anthropological Linguistics, (1985).

Arnold, Mathew.Culture and Anarchy. J.D. Wilson, ed. (Cambridge: Cambridge University Press, 1869).

Barthes, Roland. Elements of Semiology. (Macmillan, 1977).

Barthes, Roland. The Semiotic Challenge, (University of California Press, 1994)

Emberto, Eco.A Theory of Semiotics. (Bloomington: Indian University Press, 1979).

Floch, Jean-Marie.Visual identities. (Bloomsbury Publishing, 2005)

Geniole, Shawn N., and Cheryl M. McCormick."Facing our ancestors: judgements of aggression are consistent and related to the facial width-to-height ratio in men irrespective of beards."Evolution and Human Behavior 36, no. 4 (2015).

37. Luo, Jiali, and David Jamieson-Drake."Examining the educational benefits ofinteracting with international students."Journal of International Students 3, no. 2 (2013): 85-101. 
Hofstede, Geert. Culture's Consequences: International Differences in Work-Related Values. (Beverly Hills: Sage, 1980).

Katan, David.Translating Cultures: An Introduction for Translators, Interpreters and Mediators, $2^{\text {nd }}$ Ed., (Manchester: St. Jerome, 2004).

Korzhov, Nikolay. In Pictures: Myanmar's Neck Ring Women. In Pictures, (2013) retrieved from https://www.aljazeera.com/indepth/inpictures/2013/09/2013911121115463797.html. (accessed on March 5, 2018)

Luo, Jiali, and David Jamieson-Drake."Examining the Educational Benefits of Interacting with International Students." Journal of International Students 3, no. 2 (2013).

Lurie, Alison. The Language of Clothes. (Random House Inc, 1981)

Milkowski and Smith, Loonie,The Doctor Is In!, JAZZ TIMES, (2005) retrieved from http://jazztimes.com/columnS_and_features/table_of_contents/article_excerpts/index.cf m?articl_id=15242. (accessed on February 24, 2018).

Morris, Charles. Signs, Language and Behavior, (New York: George Braziller, 1946).

Pierce, Sanders Charles.The Collected Papers of C. S. Peirce, 1-6, ed. CharlesHartshorne and Paul Weiss; vols. 7-8, ed. A. W. Burks, (Cambridge: Harvard, 1931-66).

SaussuredeFerdinand.Course in General Linguistics,( New York: Mcgraww-Hill Paperbacck, 1972).

Schmid, Paul. Understanding Turbans, (The Seattle Times, NA), Retrieved from http://www.sikhinterfaithvic.org.au/Understanding\%20turbans.pdf (accessed on February 23, 2018).

Sidhu, Dawinder S and Gohil, Singh Neha.The Sikh Turban: Post 9/11 Challenges to ThisArticleto Faith.(Rutgers Journal of Law and Religion, 9: 2, 2008).

Sikh Blog, Sikh Theology Why Sikhs wear a Turban, retrieved from content/uploads/2016/02/Sikh-Theology-Why-Sikhs-wear-a-Turban.pdf.(accessed on February 22, 2018).

Sobur, Alex. Analisisteks Media: suatupengantaruntukanalisiswacana, analisissemiotikdananalisis framing. (Remaja Rosdakarya, 2001).

Stanford Peace innovative Lab, Turban myths: The Opportunity and Challenges for Reframing a Cultural Symbol for Post 9/11 America, (Stanford California, 2013).

Ström, Krister. Torshammarringen—etl i Västmanland unikt vikingatida föremål. Västmanlands fornminnesförenings årsskrift, (1973): 105-117. 
The Koh-i-noor Diamond (BBC, 2002) , 9. http://www.bbc.co.uk/dna/h2g2/A730801. (accessed on February 23, 2018) .

Trompenaars, Fons, and Charles Hampden-Turner. Riding the waves of culture: Understanding diversity in global business. (Nicholas Brealey Publishing, 2011).

Tylor, Burnett Edward. Primitive Culture: Researches into the Development of Mythology, Philosophy,, (The University of Michigan, 1871).

Watkins, Christopher D., Benedict C. Jones, and Lisa M. DeBruine. "Individual Differences in Dominance Perception: Dominant Men are Less Sensitive to Facial Cues of Male Dominance." Personality and Individual Differences 49, no. 8 (2010).

Wood, Douglas R. "Self-perceived Masculinity between Bearded and Non-Bearded Males." Perceptual and Motor Skills 62, no. 3 (1986). 